\title{
New insight into the rheumatoid vasculitis
}

\author{
M. COJOCARU ${ }^{1,2}$, INIMIOARA MIHAELA COJOCARU ${ }^{3,4}$, B. CHICOŞ ${ }^{2}$ \\ 1،"Titu Maiorescu” University, Faculty of Medicine, Bucharest \\ 2"Dr. Ion Stoia" Clinical Center for Rheumatic Diseases, Bucharest \\ 3"Carol Davila" University of Medicine and Pharmacy, Bucharest \\ ${ }^{4}$ Department of Neurology, "Colentina” Clinical Hospital, Bucharest, Romania
}

\begin{abstract}
Vasculitis in rheumatoid arthritis (rheumatoid vasculitis, RV) has a heterogeneous clinical presentation that includes skin disorders, neuropathy, eye symptoms and systemic inflammation. Rheumatoid vasculitis is an unusual complication of longstanding, severe rheumatoid arthritis (RA).

While RA affects the body's joints, vasculitis is a condition in which blood vessels become inflamed. Rheumatoid vasculitis occurs in approximately 2 to $5 \%$ of patients who have RA. The blood vessels most often involved are arteries that bring blood to the skin, nerves, and internal organs. Veins can also be involved. Rheumatoid vasculitis is skin condition that is a typical feature of RA, presenting as peripheral vascular lesions that are localized (purpura, cutaneous ulceration, and gangrene of the distal parts of the extremities). The cause of RV is unknown, but given the prominence of immune components and the pathologic changes in involved blood vessels, an autoimmune process is suggested. Compared to other forms of vasculitis, there has been relatively little research in recent years on the specific entity of RV. There is some evidence that the incidence of RV has decreased over the past several decades, perhaps because of a better treatment of the underlying RA. In the present review, we discuss the clinical features, laboratory tests, the pathogenesis of RV.
\end{abstract}

Key words: rheumatoid vasculitis, clinical features, laboratory tests, pathogenesis.

The first series of patients with rheumatoid vasculitis (RV) was published in 1951. Rheumatoid vasculitis is arguably the most serious systemic disease manifestation of rheumatoid arthritis (RA). Rheumatoid vasculitis is a rare but serious complication of RA. Vasculitis is an uncommon complication of RA (in approximately 2 to $5 \%$ of patients), males with RA are more likely (2 to 4 times more likely) than females with RA to develop RV. Rheumatoid vasculitis most often occurs in people with at least 10 years of severe disease. Fortunately, recent reports have noted declines in the prevalence of RV $[1,2]$.

Vasculitis is associated with an increase in morbidity and mortality, although systemic manifestations such as glomerulonephritis, cerebral vasculitis or pulmonary vasculitis are very rare. Cerebral RV is a serious complication which can be life-threatening [3].

Rheumatoid vasculitis is a manifestation of extraarticular (beyond the joint) RA and involves the small and medium-sized arteries in the body. Rheumatoid vasculitis can affect a person from any ethnic background, either gender, and from any age group. However, more often, the typical patient has long-standing RA with severe joint deformities from the underlying arthritis. Although the arthritis has usually led to significant joint damage, at the onset of RV the joint disease is paradoxically quiet [4].

Rheumatoid vasculitis remains an important complication of RA that needs to be promptly recognized and treated [5].

\section{CLINICAL FEATURES}

The condition occurs in patients with longstanding, severe RA. Within a given patient with RV, clinical features of both medium- and small-vessel disease may be found. Rheumatoid arthritis is a systemic inflammatory disease that can involve other tissues and organs as well as synovial joints [6]. Rheumatoid vasculitis is among the most serious complications of RA. The consequences of vasculitis depend on the size, site and number of blood vessels involved. Cutaneous manifestations are the most frequent, and often the initial feature of extraarticular involvement in patients with RV. Patients with RV nearly always have rheumatoid nodules and are present in up to $30 \%$ [7]. 
Rheumatoid vasculitis is viewed as a heterogeneous group of syndromes with varying clinical and histopathologic features, which have different prognostic implications, and therefore should be managed differently [8].

Vasculitis is also associated with most of the extra-articular manifestations described in RA. Rheumatoid vasculitis has many potential signs and symptoms. The manifestations of RV can involve many of the body's different organ systems, including but not limited to the skin, peripheral nervous system (nerves to the hands and feet), arteries of the fingers and toes causing digital ischemia, and eyes with scleritis. Scleritis (inflammation of the white part of the eye) commonly occurs in the setting of RV. In addition, generalized symptoms such as fever and weight loss are common. As it is true with other forms of vasculitis that involve the skin, cutaneous lesions can erupt on various areas of the body in RV, with a predilection for the lower extremities. Typical findings include ulcers concentrated near the ankles. Small nail fold infarcts (small spots around fingernail) can occur in RA but these do not necessarily signify the presence of systemic vasculitis and do not necessitate a change in RA treatment. Nerve damage can cause foot or wrist drop, known in medical terminology as mononeuritis multiplex. Necrotizing vasculitis is responsible for the different patterns of noncompressive neuropathies in RA, including mononeuritis multiplex and distal symmetric sensory or sensorimotor neuropathy [9].

Features of cutaneous RV overlapping both the characteristics of cutaneous necrotizing venulitis and cutaneous polyarteritis nodosa together with coexistence of these different type of vasculitis in the same or different lesional skin account for the associated diverse cutaneous vasculitic manifestations [10].

Sjögren's syndrome, anaemia of chronic disease and pulmonary manifestations are relatively common (in 6-10\%) in early disease and are all related to worse outcomes measures of rheumatoid disease, in particular functional impairment and mortality. The place for biological therapies is still not clear. Therapy depends upon the clinical manifestation of RV [11].

\section{DIAGNOSIS}

Rheumatoid vasculitis is an uncommon but potentially catastrophic complication of RA.
Rheumatoid vasculitis may suspect on symptoms of rash, skin ulcers, numbness or tingling of the hands or feet, weakness in a hand or foot, cough and shortness of breath, chest pain, abdominal pain, or stroke symptoms [12].

The diagnosis is usually made with a combination of patient medical history and symptoms, physical examination, pertinent laboratory tests, specialized tests (such as nerve conduction studies), and tissue biopsy of involved skin, muscle, nerves, or other affected organ [13].

Persons with RA who develop new extraarticular symptoms such as skin ulcerations, decreased blood flow to the fingers or toes, sensory or motor nerve dysfunction (such as numbness, tingling, weakness), inflammation of the lining of the heart or lungs, or even weight loss or fever, should be evaluated for RV [14].

Because the treatment implications for RV are major, any diagnostic uncertainty must be met with definitive approaches to establishing the diagnosis. This usually involves biopsy of an involved organ. Deep skin biopsies (full-thickness biopsies that include some subcutaneous fat) taken from the edge of ulcers are very useful in detecting medium vessel vasculitis. Nerve conduction studies help identify involved nerves for biopsy. Muscle biopsies (e.g., of the gastrocnemius muscle) should be performed at the same time as nerve biopsies, to increase the chance of finding changes characteristic of vasculitis. Imaging studies have no consistent role in the evaluation of $\mathrm{RV}$, although sometimes angiography of the gastrointestinal tract is useful. Biopsy of the skin or other symptomatic organs is sometimes necessary. Early and accurate diagnosis is imperative to choosing the most appropriate treatment to control symptoms and prevent damage [15].

\section{LABORATORY TESTS}

Laboratory tests may support, but do not confirm, a diagnosis of RV. Rheumatoid vasculitis occurs almost exclusively in patients with seropositive nodular RA. An abnormally active immune system (the body's defense system) appears to play an important role in blood vessel inflammation [16].

High titers of rheumatoid factor (RF), cryoglobulins, diminished circulating complement, an increased prevalence of HLA-DR4, and the pathologic findings suggest an immune etiology. An elevated 
erythrocyte sedimentation rate increased C-reactive protein level, anemia, thrombocytosis, hypoalbuminemia, and a positive RF are common laboratory findings. Leukocytosis, hypergammaglobinemia, leukocytopenia, an elevated creatinine level, and minimal abnormalities of the urinary sediment also occur in patients with RV [17].

Laboratory findings may include anemia of chronic inflammation, elevation of erythrocyte sedimentation rate or C-reactive protein, polyclonal hypergammaglobulinemia, cryoglobulinemia and RA associated autoantibodies. Complement levels may be dynamically decreased during active disease and, along with inflammatory parameters, may provide useful follow-up information. Most laboratory findings in RV - for example, elevations in the erythrocyte sedimentation rate or C-reactive protein are non-specific, and reflect the presence of a generalized inflammatory state. Hypocomplementemia, anti-nuclear antibodies (ANA), and perinuclear anti-neutrophil cytoplasmic antibodies (ANCA) are common. Anti-neutrophil cytoplasmic antibodies are typically detected in anti-neutrophil cytoplasmic antibody associated vasculitis, but are also present in a number of chronic inflammatory non-vasculitic conditions like RA. Rheumatoid factor levels are usually extremely elevated. However, there is no definitive laboratory test for RV short of a tissue biopsy. A perinuclear ANCA was found in $48 \%$ of patients with RV. Specific enzyme immunoassay studies for anti-proteinase-3 antibodies are typically negative in RV [18].

Some studies have shown an association between elevated RF or anti-CCP antibodies and RV. However, the high prevalence of these antibodies in RA without vasculitis lends little to a positive predictive value for the diagnosis of RV. A blood test for specific antibodies that are directed against the inner layer of blood vessels (endothelial cells) are present in approximately $75 \%$ of patients with RV compared to only 15 to $20 \%$ of those with RA alone. Therefore, this blood test may be checked regularly in patients with any of these new or worsened symptoms [12].

Co-factors for the vascular injury that we believe are integral to the skin lesions of RA include RF, anti-endothelial antibodies of $\operatorname{IgA}$ class, anti-SS-A and anticardiolipin antibodies.

Rare cases of granulomatosis with polyangiitis (formerly known as Wegener's granulomatosis, a vasculitic disorder frequently associated with the presence of ANCA) in patients with RA have been described in literature [13].
Cutaneous vasculitis, multifocal neuropathy, and depressed $\mathrm{C} 4$ level were the 3 independent variables which best predicted mortality [14].

However, these abnormalities overlap in patients with uncomplicated RA, and their role in distinguishing RV from uncomplicated RA is limited.

In summary, characteristic histopathology confirmation of vasculitis is generally necessary for a diagnosis of $\mathrm{RV}$.

\section{PATHOGENESIS}

Vasculitis may accompany RA. The cause of clinical VR is unknown. Rheumatoid vasculitis refers to a destructive, inflammatory process that is centered on the blood vessel wall itself. RV leads to necrosis, blood vessel occlusion, and tissue ischemia. The molecular mechanisms underlying $\mathrm{RV}$ are not fully understood; however, the importance of a chronic imbalance of the cytokines and chemokines involved in orchestrating inflammatory responses is well established in patients with RA, and similar dysregulation of these mediators has been suggested to occur in patients with RV [15].

Rheumatoid vasculitis refers to patients with RA, a chronic disease with painful inflammation of the joints, who also develop inflammatory disease in small and medium-sized blood vessels. RV leads to necrosis. Rheumatoid vasculitis usually develops at a time when the inflammatory arthritis is "burned out", (e.g., when the erosive process that led to joint destruction has become less active) [16].

Rheumatoid vasculitis most commonly occurs in the skin as venulitis or capillaritis, meaning the very smallest blood vessels are affected by inflammation from the disease. Genetic factors may be involved. Viral infections and drug reactions have been suggested as causes of RV, but there is little research to support this. Some research suggests that long time use of drugs such as corticosteroids, azathioprine that are used to treat RA can cause the development of RV [17].

The association of RV with RF and autoantibodies (e.g., anti-cyclic citrullinated polypeptide [CCP], antinuclear antibodies) suggests that immune complex disease may be causative. Immune complexes may be found in the affected tissue, and most patients with RV have circulating autoantibodies. However, many patients with RA who have circulating or tissue-deposited immune 
complexes and high levels of autoantibodies do not develop vasculitis [18].

The relationship of these immune complexes to RA and vasculitis leaves many unanswered questions and is far from definitive. Evidence linking the immune system to vasculitis includes: high levels of RF, the presence of immune complexes, lower levels of complement, which are used up when inflammation occurs, the appearance of inflamed blood vessels under the microscope, which shows immune cells within the wall of the vessel [19]. The most devastating form of RV is characterized by a medium-sized vasculitis [20].

Even in recent years, RV remains a serious complication of RA and is associated with significant mortality [21].

\section{CONCLUSIONS}

Systemic vasculitis is a rare but serious complication of RA and may be considered one of the most serious extraarticular consequences of this disease. Rheumatoid vasculitis is a clinicopathologic manifestation of RA characterized by tissue damage or ischemia. Rheumatoid vasculitis may involve virtually any organ of the body. In general, people who get vasculitis have many joints with pain and swelling, rheumatoid nodules, high concentrations of RF in their blood, and sometimes smoke cigarettes. Rheumatoid vasculitis manifests almost exclusively in patients with rheumatoid autoantibodies. Biopsy is typically required to ensure a definitive diagnosis of RV.

Vasculita din cadrul poliartritei reumatoide (PR) se prezintă clinic polimorf, cuprinde modificări cutanate, neuropatie, simptome oculare ş̧i inflamație sistemică. Vasculita reumatoidă (VR) este o complicație neobişnuită a PR severe cu evoluție îndelungată. In timp ce PR afectează articulațiile, vasculita este o stare in care vasele sanguine sunt inflamate. Vasculita reumatoidă se intâlnește la aproximativ 2-5\% dintre pacienții cu PR. Vasele sanguine cel mai adesea afectate sunt arterele care vascularizează pielea, nervii şi organele interne. Venele pot, de asemenea, să fie afectate. Vasculita reumatoidă este modificarea cutanată tipică în $P R$, se prezintă cu leziuni vasculare periferice care sunt localizate (purpura, ulcerații cutanate, gangrena extremităților). Cauza VR este deocamdată neelucidată, din cauza prezenței componentelor imune şi modificărilor patologice la nivelul vaselor sanguine afectate s-a sugerat un proces autoimun. Comparativ cu alte forme de vasculite, există puține cercetări în ultimii ani referitoare la VR. Unele rapoarte evidențiază că incidența VR a scăzut în ultimele decade datorită tratamentului eficient în PR. În acest referat, autorii discută despre trăsăturile clinice, patogenia şi testele de laborator în VR.

Corresponding author: Univ. Assoc. Prof. Dr. Manole Cojocaru

5, Str. Thomas Masaryk, Sector 2,

Postal Code 020983, Bucharest, Romania

E-mail address: mancojocaru@yahoo.com

\section{Author contribution}

All authors have contributed equally to the present work.

The authors declare no conflict of interest.

\section{REFERENCES}

1. ALAMANOS Y, VOULGARI PV, DROSOS AA. Incidence and prevalence of rheumatoid arthritis, based on the 1987 American College of Rheumatology criteria: a systematic review. Semin Arthritis Rheum 2006; 36(3): 182-8.

2. VOLLERTSEN RS, CONN DL. Vasculitis associated with rheumatoid arthritis. Rheum Dis Clin North Am 1990; 16(2): 445-61.

3. KHASNIS A, LANGFORD CA. Update on vasculitis. J Allergy Clin Immunol. 2009; 123: 1226-36.

4. YOUNG A, KODURI G. Extra-articular manifestations and complications of rheumatoid arthritis. Best Pract Res Clin Rheumatol 2007; 21(5): 907-27.

5. GENTA MS, GENTA RM, GABAY C. Systemic rheumatoid vasculitis: a review. Semin Arthritis Rheum. 2006; 36: 88-98.

6. TURESSON C, MATTESON EL. Vasculitis in rheumatoid arthritis. Curr Opin Rheumatol. 2009; 21(1): 35-40.

7. WATTS RA, MOONEY J, LANE SE, SCOTT DG. Rheumatoid vasculitis: becoming extinct? Rheumatology. 2004 ; 43: 920-3. 
8. BARTELS CM, BRIDGES AJ. Rheumatoid vasculitis: vanishing menace or target for new treatments? Curr Rheumatol Rep 2010; 12(6): 414-9.

9. MAKOL A, MATTESON EL, WARRINGTON KJ. Rheumatoid vasculitis: an update. Curr Opin Rheumatol 2015; 27(1): 63-70.

10. MAKOL A, CROWSON CS, WETTER DA, SOKUMBI O, MATTESON EL, WARRINGTON KJ. Vasculitis associated with rheumatoid arthritis: a case-control study. Rheumatology (Oxford). 2014; 53(5): 890-9.

11. NTATSAKI E, MOONEY J, SCOTT DG, WATTS RA. Systemic rheumatoid vasculitis in the era of modern immunosuppressive therapy. Rheumatology (Oxford) 2014; 53(1): 145-52.

12. KANEKO S, YAMASHITA H, SUGIMORI Y, TAKAHASHI Y, KANEKO H, KANO T, MIMORI A. Rheumatoid arthritisassociated aortitis: a case report and literature review. Springerplus 2014; 3: 509.

13. JAMES W, BERGER T, ELSTON D. Andrews' Diseases of the Skin: Clinical Dermatology. (10 ${ }^{\text {th }}$ ed.). Saunders. 2005.

14. RAPINI RP, BOLOGNIA JL, JORIZZO JL. Dermatology: 2-Volume Set. St. Louis: Mosby. 2007.

15. MAGRO CM, CROWSON AN. The spectrum of cutaneous lesions in rheumatoid arthritis: a clinical and pathological study of 43 patients. J Cutan Pathol 2003; 30(1): 1-10.

16. CHEN KR, TOYOHARA A, SUZUKI A, MIYAKAWA S. Clinical and histopathological spectrum of cutaneous vasculitis in rheumatoid arthritis. Br J Dermatol 2002; 147(5): 905-13

17. PUÉCHAL X, SAID G, HILLIQUIN P, COSTE J, JOB-DESLANDRE C, LACROIX C, MENKÈS CJ. Peripheral neuropathy with necrotizing vasculitis in rheumatoid arthritis. A clinicopathologic and prognostic study of thirty-two patients. Arthritis Rheum 1995; 38(11): 1618-29.

18. ZOLCINSKI M, BAZAN-SOCHA S, ZWOLINSKA G, MUSIAL J. Central nervous system involvement as a major manifestation of rheumatoid arthritis. Rheumatol Int. 2008; 28: 281-3.

19. AKROUT R, BENDJEMAA S, FOURATI H, EZZEDDINE M, HACHICHA I, MHIRI C, BAKLOUTI S. Cerebral rheumatoid vasculitis: a case report. J Med Case Rep 2012; 6: 302.

20. MRABET D, MEDDEB N, AJLANI H, SAHLI H, SELLAMI S. Cerebral vasculitis in a patient with rheumatoid arthritis. Joint Bone Spine 2007; 74(2): 201-4.

21. CABALLOL PONS N, MONTALÀ N, VALVERDE J, BRELL M, FERRER I, MARTINEZ-YÉLAMOS S. Isolated cerebral vasculitis associated with rheumatoid arthritis. Joint Bone Spine 2010; 77(4): 361-3.

22. LASKARI K, AHMADI-SIMAB K, LAMKEN M, et al. Are anti-cyclic citrullinated peptide autoantibodies seromarkers for rheumatoid vasculitis in a cohort of patients with systemic vasculitis? Ann Rheum Dis. 2010; 69: 469-71.

23. SPOERL D, PERS YM, JORGENSEN C. Anti-neutrophil cytoplasmic antibodies in rheumatoid arthritis: two case reports and review of literature. Allergy Asthma Clin Immunol 2012; 8(1): 19.

24. RUIZ-ZORRILLA A, PICAZO M, GONZÁLEZ-ÁLVARO I, GÓMEZ-GIL R, GARCIA DE VICUNA R. Vasculitis associated with anti-neutrophil cytoplasmic autoantibodies in rheumatoid arthritis. Report of a case of microscopic polyangiitis and another case of Wegener's granulomatosis. Reumatol Clin 2005; 1(1): 52-5. 